\title{
Education, Development, and Wage Inequality: The Case of Taiwan
}

James P Vere

Economic Development and Cultural Change; Apr 2005; 53, 3; ABI/INFORM Global pg. 711

\section{Education, Development, and Wage Inequality: The Case of Taiwan}

\author{
JAMES P. VERE \\ University of Hong Kong
}

\section{Introduction}

Changes in income ineequality over time have been a subject of long-standing interest among economists, particularly in a develepment context. The first theory proposing a relationship berween the rwo was Kuznetsis (1955) hypothesis that the expansion of an industrial secter will catuse per capita incence inceguality to rise until the industrial sector begins tes deminate the andicultural sector, at which point inequality will tall asain. Since then, a flexd of research has examined the retationship not only between incyuality and industrializattion but also between inceguality and a number of processes also associared with development. These processes include thanges in inderstrial struchure, factor-specific technical change educational expansion, population aging and the feminization of the labor force. Yet, since these prexesses are offere concurrent, their relative importance at different stales of an ecomomy development is rarely obvious.

Kuznets's hypothesis was grounded in the carly experiences of lingland. Germany, and the United States, all of which started to industrialize well betore the other processes mentioned began to take roser. For example. Kunnets notes that inequality in the United Sades started to rise from $1 s^{-0}($ onward: this preceded the expansion of secondary scheol education in the Lnited states by nearly a decades. Women did not start entering the Lis. labor force in carnest until the lyos, and the effects of the postwar decline in tertility on rhe population sage structure will not be fully fede unt il well inte the awentyfirst century. The effects of the first three of these presesses on the lis. winge structure have been well documented (Kuznets 1955: (ioldin and Kaes lece); Juhn and $\mathrm{Kim}$ (99)), and if the United states follows Japan's example, che fourth is but a matter of time (Ohatite and saito leys's.

In the experience of more recenty developing countries, however. these

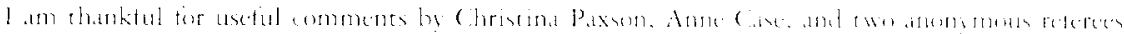

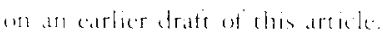




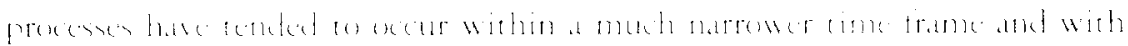

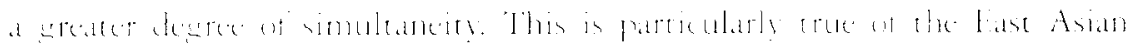

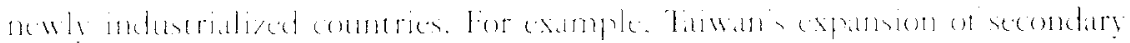

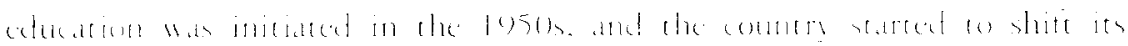

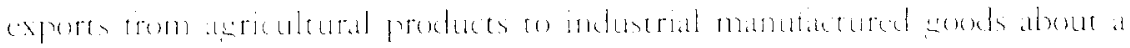

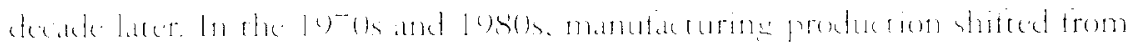

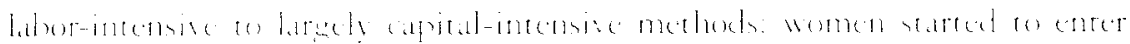

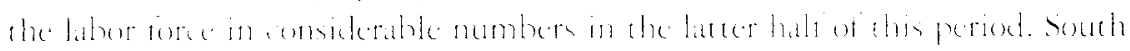

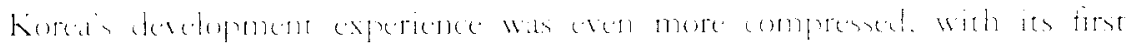

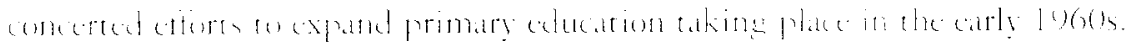

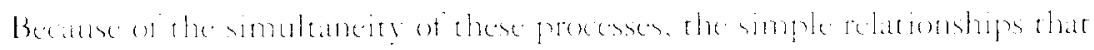

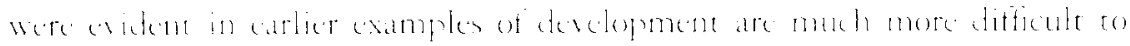

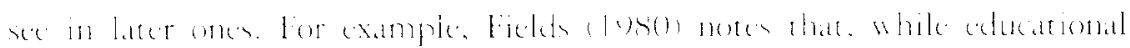

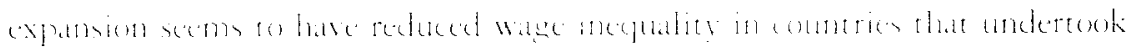

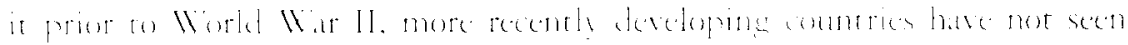

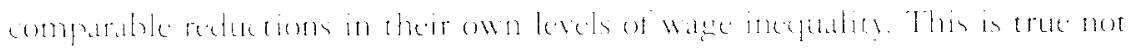

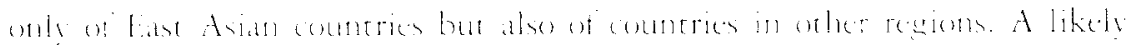

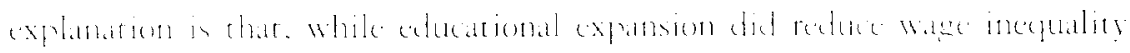

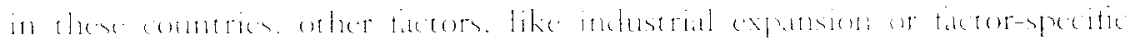

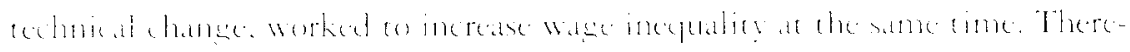

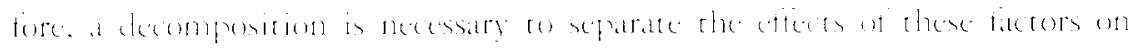

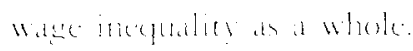

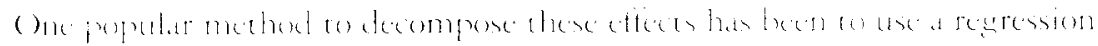

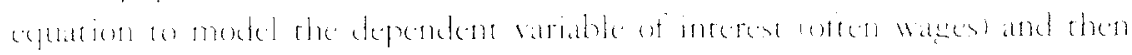

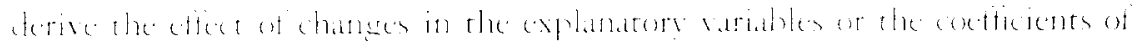

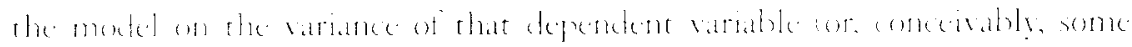

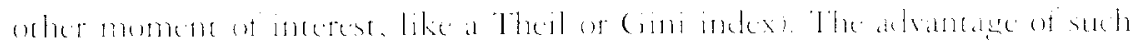

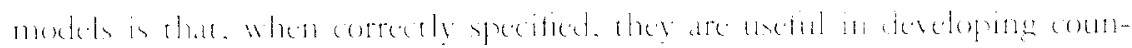

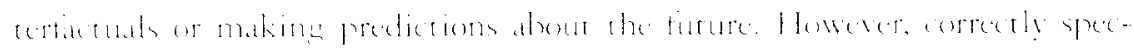

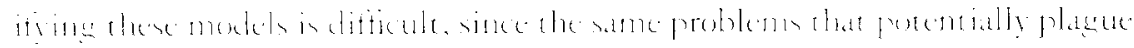

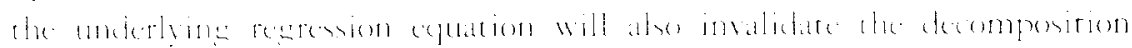
realis

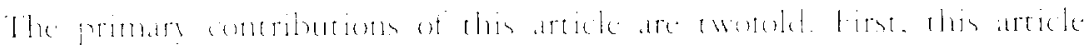

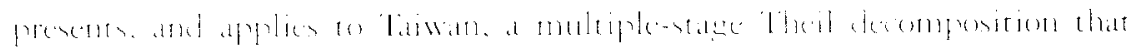

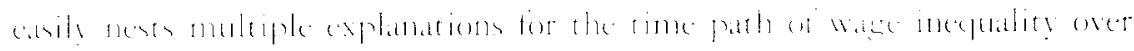

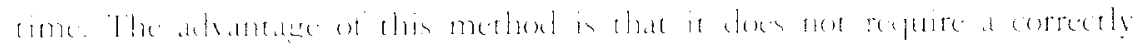

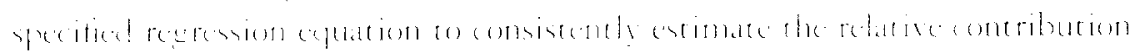

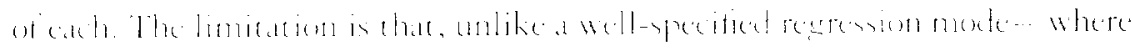

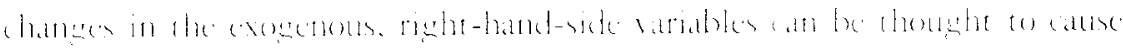

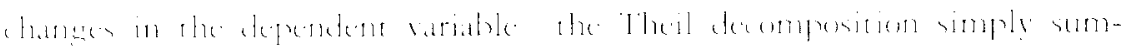


marizes features of the data and saly nothing about the direction of camblity: An adelitional point is that the results from this decomposition can change depending on which variables are included; the results tor any particular variable must be interpreted in lighe of others present. Mulrivartate inequality decomprestions in the literature so far have focuscel on the regression approath virtually exclusively.

second, this article sheds new light on the debate on wage inceptatity for Tawan itself. It is no secret that Tawan's derelopment experience has heen exceptional, and Tawan is certainly not an cxample of a typical developing country. However, the presence of a large number of potential explantations for changes in Taiwan's wage structure has presented consensus as ro which of these explanations are the most important.

From the perspective of labor supply, the literature has jetencified at number of factors that woukt be expeced to reduce ware inecpuality. Most of these factors are related to Taiwan's educational expansion. For example, using data from the May supplements of Taiwan's Labor Force Surveys throueh lex)l, Gindling. (joldtarb, and Chang (1095) observe a generalized decline in the wage return to educition for graduates with a lower secondary gualification

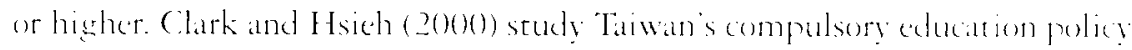
with similar data and an cye toward using year of birth as an instrumente to masure the return to a year of schooling in Taiwan. They find that deing so senerates instrumental variables (IV) estimates of the return to celuation that are significanty lowe than the corresponding OLS estimates. They arese that the is because of the significanty greater supply of educated pratuates in Taiwan after the compulsory education poticy in linwan took effect. Finally, (iindling and Sun (20) 2) use Katz and Murphys (109) merhedelong to explicity test whether changes in the supply of educated sraduates, in the absence of any shifts in demand, are sufficient to explain changes in laiwans wase structure and conclude that they are.

Population aging and the entry of women into the labor force, however,

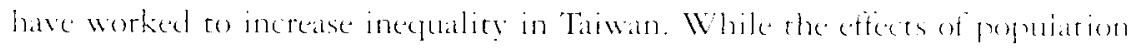
deing have reccived liete attention from the perspective of wase ine quality, Daton and Paxson (199) f) find a slight increase in incepuality of consumpron across houscholds between $19^{-6}$ and 1900 and attribute it to the asing of 'Fawan's popularion, and Schule $(1099)$ finds an analogens resule for income incequality: Moreover, since women ended to enter Taiwan's laber force at the low cond of the skill distribution, particularly in the losols, their increased tabor force participation can also be expected to increase wage incegualits (Kacglich, Rodgers, and Rodgers 19)-).

From a demand perspecrive, increases in the demand for skilled latore are 


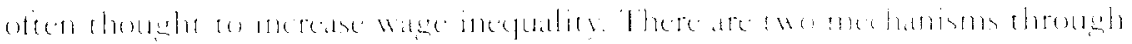

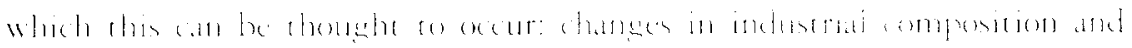

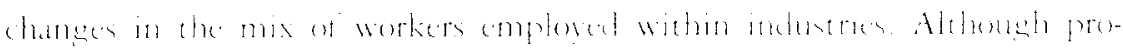

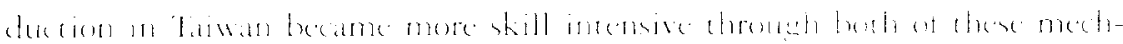

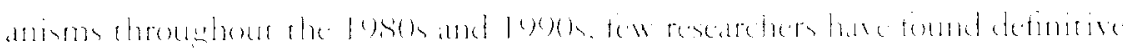

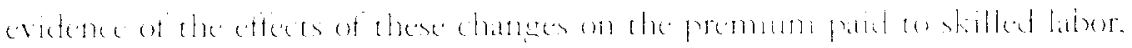

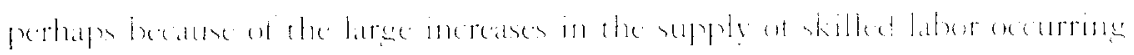

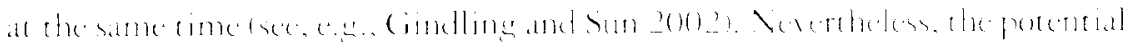

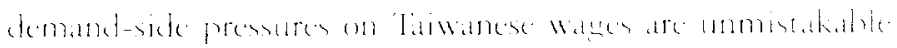

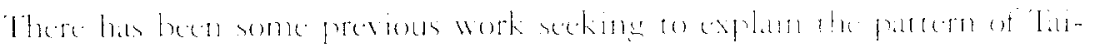

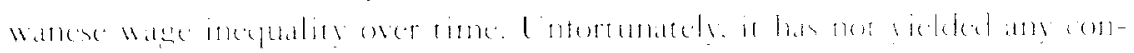

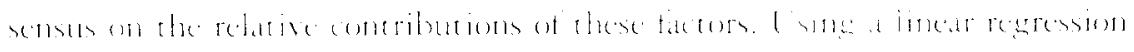

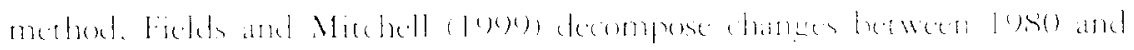

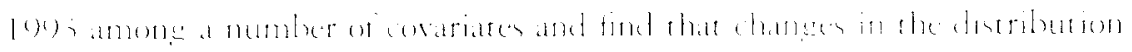

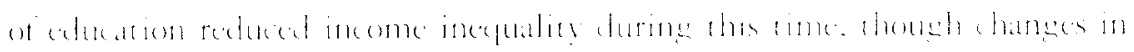

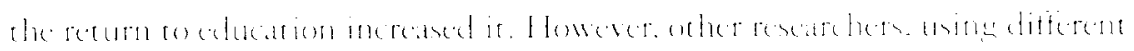

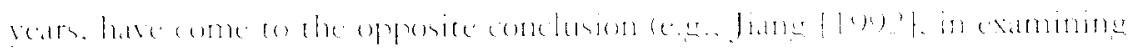

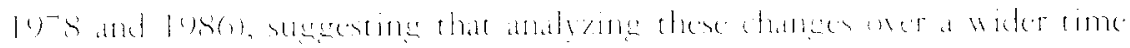

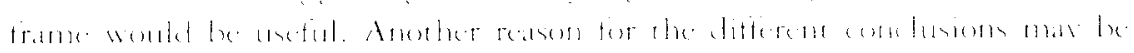

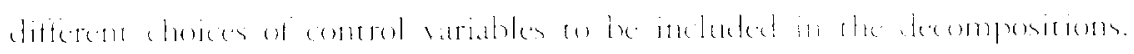

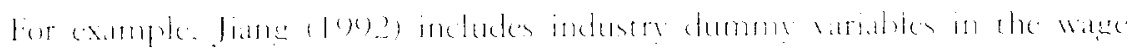

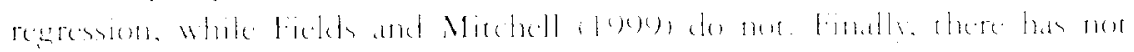

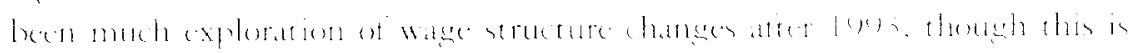

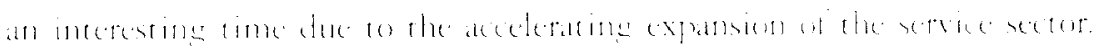

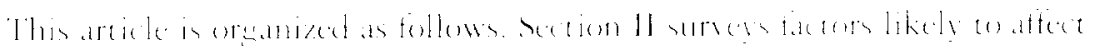

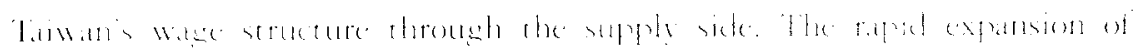

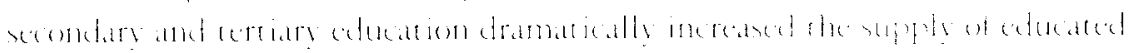

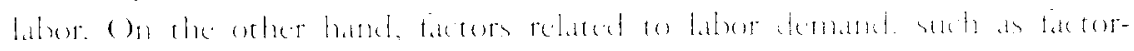

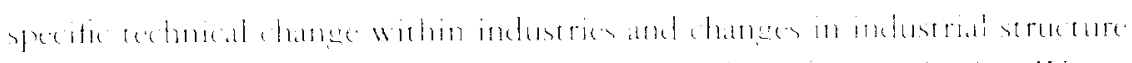

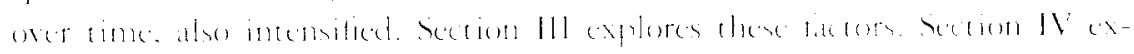

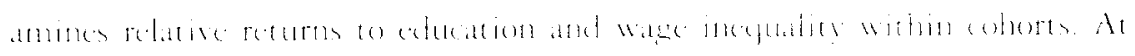

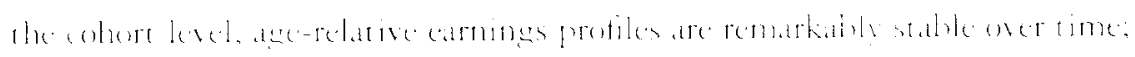

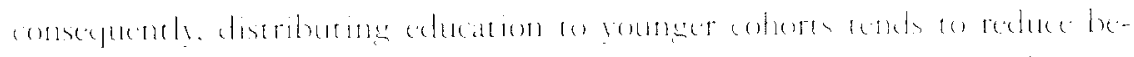

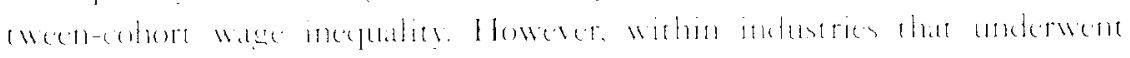

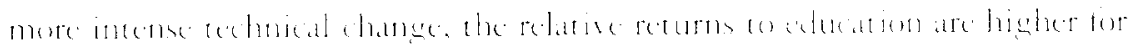

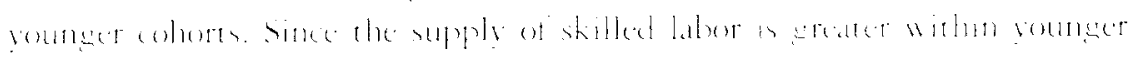

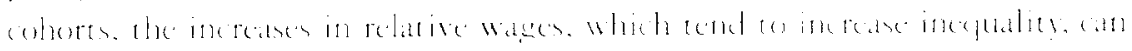

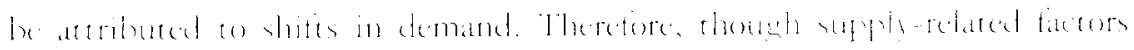

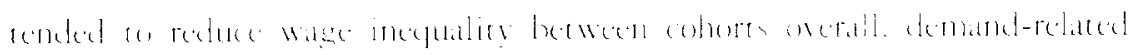

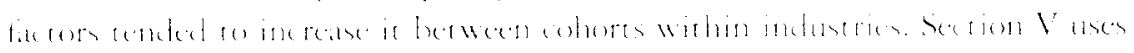


a multiple-stage Theil decomposition to formalize these promes sepatrating wage inecuality into components that capture the effects of the entry of increasingly educated gounger cohorts. changes in industrial compenition. fia tor-specific technical change, and the entry of women inte the babor forese (ot these, the first and third are the most important, with the entry of inc reasingly aducated younger cohorts explaning much of the incepualieg decline in the 1980s and factor-specific echnical change accounting tor a siznitican portion of the rise in inceptiality in the 1900s. Section VI concludes

\section{Taiwan's Educational Expansion}

\section{A. Historical Background and Implementation}

By the middle of the 1950s, it became wident in Tiawan that whe structure of the educational system, in which a very high proportion of scherstales children atended primary school but far tewer went beyond that. Was in necet

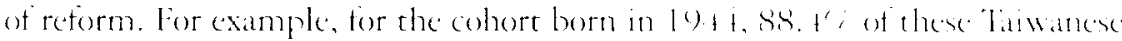
completed primary school but only i.t."; went on to complete any hishet level. Although opportunities for attending lower econdary school were relatively tew at the cime, the demand for such education had accelenated a the poine where the stresses imposed on children by the competitive entmance examination system had begun to reach an extrente level. To have a chance at one of the coveted places in lower secondary meane, at the very leats longe hours of private supplementary classes and even longer hours of extra soudy.

In the face of such strong demand by parents for more celucation for their

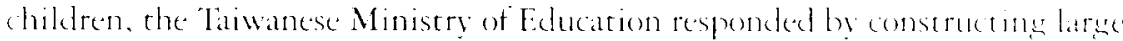
numbers of lower secondary shools with the overarching geal of remoring the examination reguirement. The intent was to provide a place in the lexal lower secondary school for all students who wished to attemed. Although the Ministry of Education had hored to construct enough shools hy lo55, and it hept up its school construction project until well past then, hy 1905 the widely criticized examination system for lower secondary places still persisted. At the same time, membership requirements of the International labor (o) sannation torbade the use of workers under the age of 1 h, so what to do with the island's childen ated 12-1 t had becone a growing social problem.

In this climate, the Taiwanese government under Chiang Kai-shete ordered the Ministry of Education to continue its school-building project with the eroal of implementing ye years of compulsory colucation by lo-(0) This date

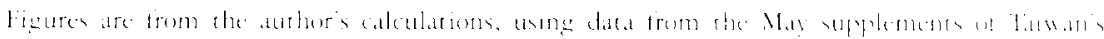

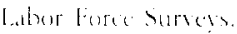


TABLE 1

PERCENT PRIMARY SCHOOL STUDENTS PROMOTED TO LOWER SECONDARY SCHOOL, BY YEAR

\begin{tabular}{lc}
\hline Year & Percent Promoted \\
\hline 1950 & 31.78 \\
1956 & 47.75 \\
1961 & 53.79 \\
1966 & 59.04 \\
$1971^{\star}$ & 80.85 \\
1976 & 90.41 \\
1981 & 96.77 \\
1986 & 99.04 \\
1991 & 99.28 \\
1996 & 98.89 \\
\hline
\end{tabular}

Source. Education Statistical Indicators, Republic of China, Ministry of Education, Taiwan, April 1999

* First measured year under the compulsory education policy.

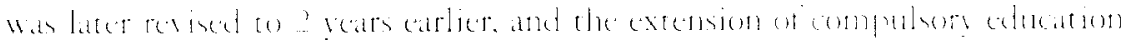

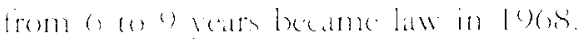

\section{B. Outcomes}

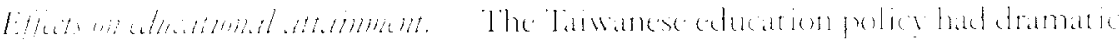

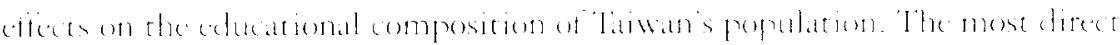

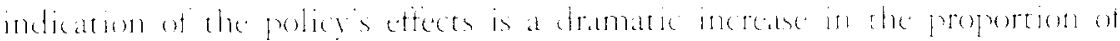

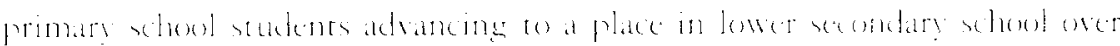

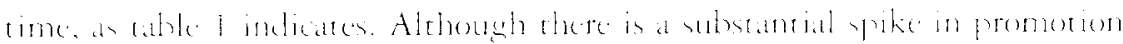

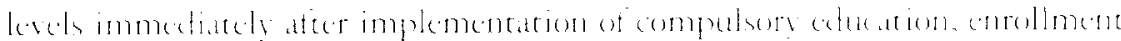

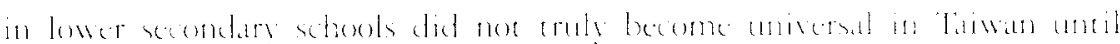
. 130,11090

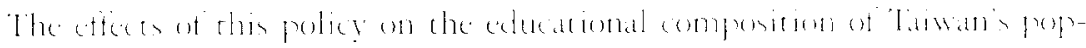

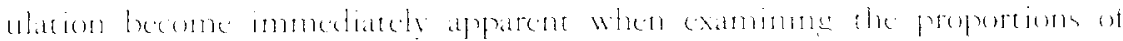

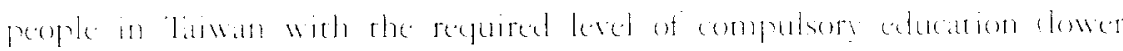

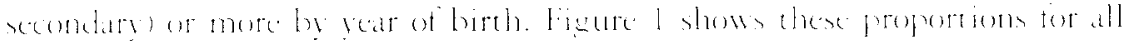

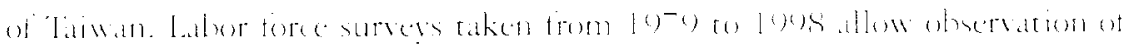

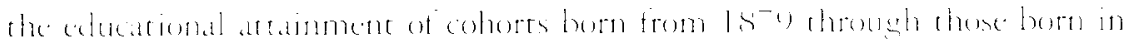

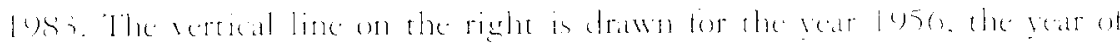

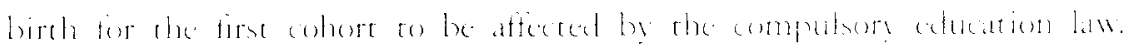

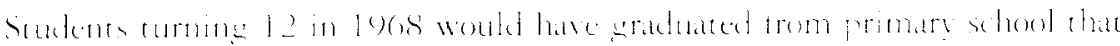

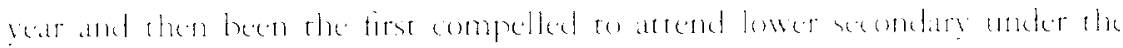

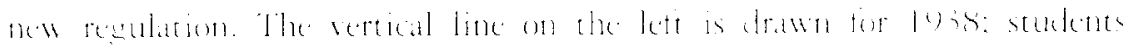

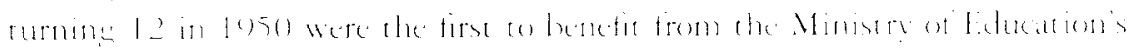




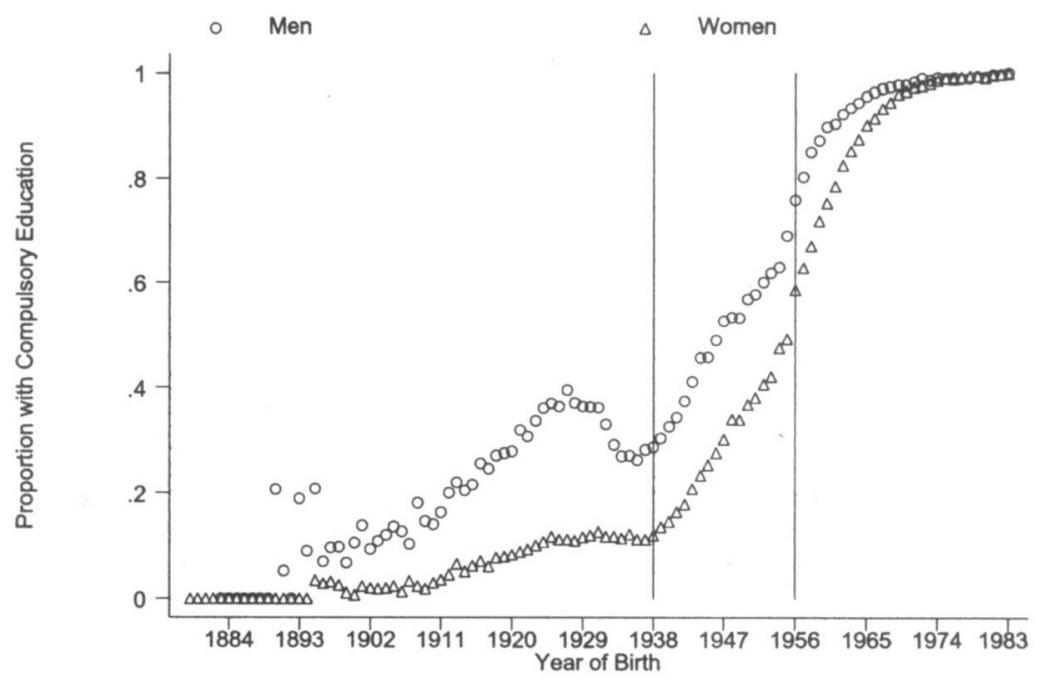

Figure 1. Proportion of men and women in Taiwan with 9 years of education or more, by year of birth

continuing school construction plan. It should be noted that since these estimates were constructed from a currenty living populations, and mortality diminishes with educational attainment, the carly figures maly hare some upward bias.

It is clear that educational attanment in Tawan had beeten on the rise even betore the compulsory education policy. The risinge trend in calucatonal at tainment before then is a result of policies of Japanization undertaken during Japan's colonial rule of the istand from 1895 to 19.45 . It had been the view of the Japanese colonial government that using the calucational sysecm to improve literacy and promote cultural assimilation would be the best strategy for the colony's long-term stability and coonomic sucesss ('Tsurumi lesta Hermalin, Liu, and Freedman 109). The dip in educational attanment immediately eo the left of the 1938 line is ateributahle to chates caused by World War II and the Nationalists closing of Japanese shools and repartating Japanese teachers upon taking power in 19.15. Some of the bulge immediately prior, however, represents immigration from the mandand with the arrival of the Nationalist army, members of which tended (o) be born in the 10?0). About a million in number, and many of them soldiers and officials. they had more education than the lecal Taiwanese who were born at about the same time (Kimmer et al. 1998).

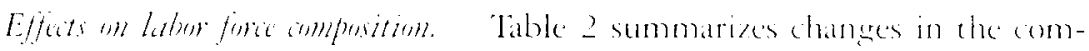
position of taiwan's labor fores berween a number of difterent demographic sroups, both over time and by birth cohort. The quantities given are the 
TABLE 2

GENDER AND EDUCATIONAL COMPOSITION OF TAIWAN'S LABOR FORCE, BY YEAR AND BIRTH COHORT (PERCENTAGES)

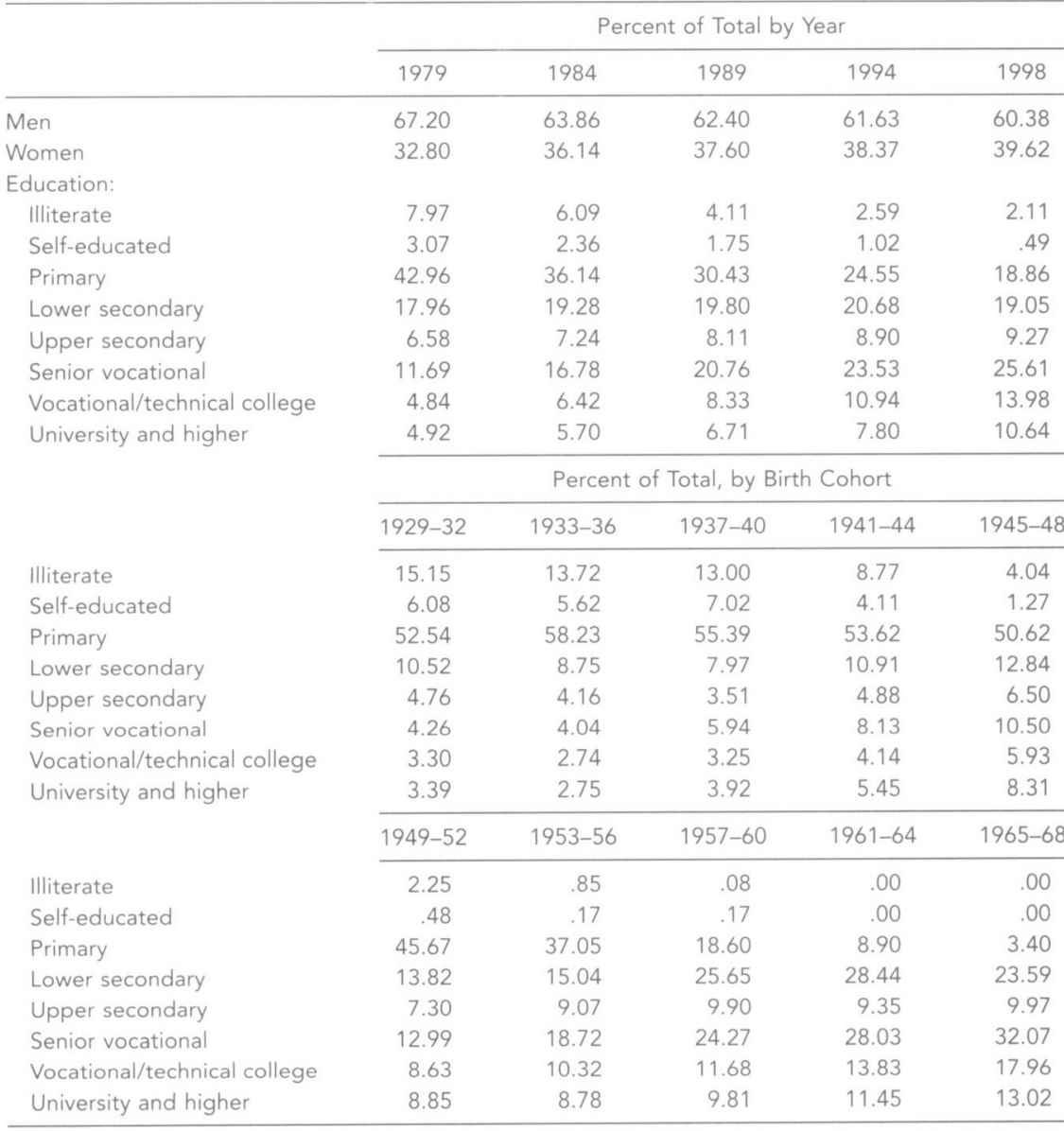

Source. Taiwanese Labor Force Survey, Directorate-General of Budget, Accounting, and Statistics, Taiwan, Taipei, various years.

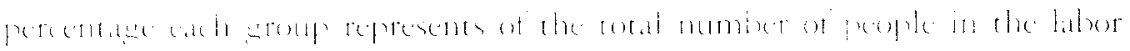

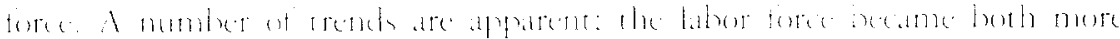

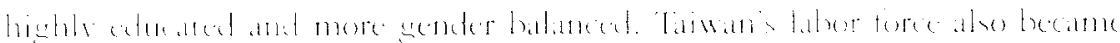

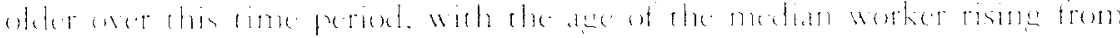

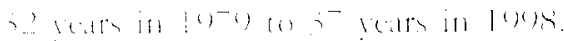

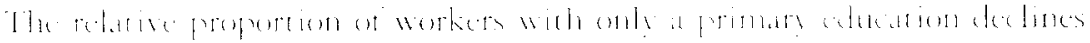

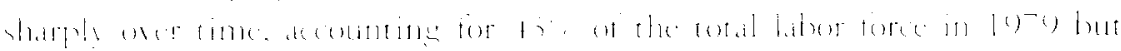

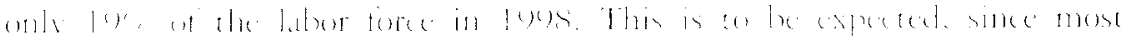


entrants to the labor force over this time period were young people completing their schooling and most of those exiting were older retirees.

Most of the new workers entering the labor force, however, did not stop at merely the level of education they were required to attain. The proportion of lower secondary workers entering the labor force increased in successive birth cohorts through 1961 and then decreased in favor of workers opting either for vocational training (representing at least 12 years of education) or a university degree. As a result, the proportions of workers in the labor force from higher educational groups all posted strong increases over time, with the proportion of workers graduating from vocational and technical colleges increasing the most swiftly from 1979 to 1989. From 199.4 to 1998, however, the proportion of workers with university degrees and higher qualifications grew the most rapidly.

In summary, there were profound and rapid changes in the educational attainment of Taiwan's population across birth cohorts. While less than half of students born between 1945 and 19-48 went on to any education past primary school, for the cohore born 20 years later, 3 years of secondary educarion had become universal and al most three-quarters of students exceeded this mark. Accordingly, the supply of educated graduates, particularly young educated graduates, in Taiwan's labor force increased rapidly from 1979) through 1998. To put these changes into perspective, the educational composition of the U.S. labor force underwent a similar change from the late 19.40s to the late 197()s.

\section{Taiwan's Industrialization and Technology Upgrading}

\section{A. Industrial Policy and Development after 1979}

In addition to Tawwan's labor force, the industrial sector also underwent significant changes over the 1980s and 1990s. Before 1979, Taiwan's industrial strategy was highly export oriented, seeking to capitalize on its extremely inexpensive, yet highly educated, labor force. Competition between the United States and Japan was intense, especially in plastics, electronics, and textiles. This forced U.S. manufacturers to look overseas for ways to cut costs, especially for skilled labor. Japan's Ministry of Trade and Industry also encouraged industries to invest abroad, especially those that were more labor intensive or technologically simple. Taiwan, seeking to benefit from these new Hows of American and Japanese investment, took steps to adjust its industrial base accordingly (Gold 1986).

Unfortunately, this strategy started to falter in the mid-1970s. Rising protectionism increasingly hindered Taiwan's exports, especially in the Inited States. In addition, other newly industrializing countries were starting to compete in the same product markets. Exporters profit margins were eroded 
by rising local wages, and, in the political sphere. Tawan lost diplomatic recognition from Japan and the United Nations. This unnerved foreign firms further. leading to capital flight and the emigration of skilled personnel to the Inited States (Wade I990)).

In this environment, the Taiwanese government in 1979) launded a new policy to shift the focus of 'Tawan's industrial development from capital-intensive, heavy industries to technology-intensive, nonpolluting, and non-energyintensive industries. 'To provide the necessary infrastructure, the government instituted and funded rescarch and development institutes and provided a number of incentives for the development of high-tech industries (van Hoesel 1999). It also actively sought to promote industrial automation and technology transfer, sometimes even providing venture capital for joint local-toreign enterprises. Some policy levers, such as import tarifts and export incentives, ran afoul of World Trade (Organization (W'T()) regulations and were abandoned by the 1990s. Nevertheless, the government remained highly involved in research and development; in the 1980s, government-sponsored research made up nearly half of all industrial research spending, and in the $199($ )s the proportion was about a third (Amsden and Chu 2003).

\section{B. Outcomes}

Effets on prodetion. Taiwan's technology policy had substantial effects, particularly in the manufacturing sector. One way to assess technical change in production is by examining the capital-labor ratio. In manufacturing, fixed assets per employee for Tawanese firms more than doubled from [SS\$7, 150 in 19\% 6 to USS14,610 in 1986. For foreign firms, the difference was even greater. In these firms, fixed assets per employee more than tripled over the

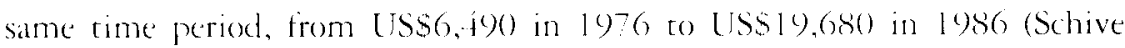
and $\mathrm{Tu}$ (0) 1 ).

Ancedotal evidence from more specific industry studies also indicate substantial changes in the character of production in Tawwanese manufacturing. For example, in the garment industry, Gereffi and Pan (199) note that Taiwanese apparel firms shifed from largely manufaturing the garments themselves to providing raw materials and machinery to garmene factories in places where labor was much less expensive.

Taiwanese bicycle producers rook a similar tack, locating assembly facilities in China and focusing marketing efforts in developed countries. The role of the grovernment was to subsidize the design of ever higher cpuality bicycles, which, in turn, required progressively more sophisticated parts. Most of these parts were manufictured in Taiwan, and local producers continually upgraded their capacity in order to meet the demands of ever more advanced designs. 
However, lags between these designs and local producers' capacity to mect the specifications sometimes required importing high-end parts from Japan, particularly in the early 1990s (Amsden and Chu 2003).

This pattern of industrial upgrading was repeated in many inclustries, particularly in electronics and information technology. In each one, Taiwanese firms sought to exploit low-cost labor overseas, realize economies of scalc through automation and mass production, and focus on core competencies of project execution, production engineering, and integrative design.

Although the service sector was not an active focus of government policy, it nevertheless developed in step with the manufacturing sector. This occurred because large business groups frequently sought to enter services as a way to diversify their revenue, especially those in industries where technological change was less swift. For example, the President Group, foreseeing that competition with China would threaten its core food-processing business, extended its operations into distribution and retailing (Amsten and Chu 2()(5).3).

Effects on labor force composition. One of the most remarkable aspects of Taiwan's industrial development in the late 1980s and 1990s is the reversal of the "brain drain" that occurred 2 decades earlier. In 1965, the IJ.S. adoption of shills-based immigration criteria resulted in a Hood of Taiwanese college graduates migrating to the United States for further study and then remaining for employment. By the 1980s, Taiwan sent more candidates for PhD engineering study than any other country. Stunningly, these candidates sometimes made up entire graduating classes in these fields from Taiwan's top three universities. Not finding any employment opportunities at home, most did not return after completing their degrees, to the considerable embitterment of Taiwanese policy makers (Saxenian and Hsu 2(0)1). In this respect, some felt that Taiwan's investment in higher education had been a colossal policy mistake, with much of the benefit being reaped by Silicon Valley.

By the late 1980s and early 1990s, however, a number of these overseas Taiwanese had started to return, bringing their acquired knowledge of production methods with them. Local demand for their talents was much greater; where before there had been a dearth of employment opportunities, now they were actively sought after, and many were enticed back with offers of highranking positions or venture capital to found their own firms ( $\mathrm{Li} 1995$ ). Numbering about 1,000 annually, these returnees represented only a small part of the total labor force in these industries (in 1989, the manufacturing sector employed about 2.7 million people, 100,000 of whom had a college degree or higher). Nevertheless, their experience highlights a tremendous shift in the demand for workers at the highest skill levels.

Aggregate statistics also suggest changes in the demand for skill within 
TABLE 3

INDUSTRIAL COMPOSITION OF TAIWAN'S LABOR FORCE, BY YEAR

\begin{tabular}{|c|c|c|c|c|c|}
\hline & \multicolumn{5}{|c|}{ Percent of Total, by Year } \\
\hline & 1979 & 1984 & 1989 & 1994 & 1998 \\
\hline Agriculture and mining & 17.9 & 14.3 & 10.5 & 8.5 & 6.8 \\
\hline Construction & 8.8 & 7.6 & 8.2 & 11.9 & 10.3 \\
\hline Manufacturing & 35.3 & 36.7 & 36.4 & 29.3 & 29.8 \\
\hline Communications, transport, and utilities & 6.9 & 6.5 & 6.1 & 6.0 & 5.8 \\
\hline Wholesale and retail trade & 13.6 & 15.8 & 17.9 & 19.3 & 19.9 \\
\hline Finance, insurance, real estate & 1.3 & 1.6 & 2.4 & 3.5 & 4.3 \\
\hline Business services & .9 & 1.0 & 1.5 & 2.4 & 2.9 \\
\hline Social and personal services & 11.0 & 12.3 & 13.1 & 15.3 & 16.4 \\
\hline \multirow[t]{2}{*}{ Public administration } & 4.4 & 4.3 & 4.1 & 3.8 & 3.7 \\
\hline & \multicolumn{5}{|c|}{ Average Years of Education, by Year } \\
\hline Agriculture and mining & 5.0 & 5.5 & 5.7 & 6.5 & 6.9 \\
\hline Construction & 6.8 & 7.7 & 7.9 & 8.9 & 9.5 \\
\hline Manufacturing & 8.2 & 8.7 & 9.4 & 9.9 & 10.6 \\
\hline Communications, transport, and utilities & 9.3 & 9.8 & 10.1 & 10.6 & 11.2 \\
\hline Wholesale and retail trade & 8.2 & 9.1 & 9.8 & 10.5 & 10.9 \\
\hline Finance, insurance, real estate & 12.4 & 12.7 & 12.6 & 12.9 & 13.4 \\
\hline Business services & 11.7 & 12.0 & 12.4 & 12.6 & 13.1 \\
\hline Social and personal services & 10.3 & 10.7 & 11.2 & 11.5 & 12.0 \\
\hline Public administration & 11.3 & 11.7 & 12.1 & 12.9 & 13.3 \\
\hline All workers & 8.0 & 8.8 & 9.5 & 10.2 & 10.9 \\
\hline
\end{tabular}

Note. Taiwanese Labor Force Surveys, Directorate-General of Budget, Accounting, and Statistics, Taiwan, Taipei, various years.

the manufacturing sector. Some statistics relating to employment in manufacturing and other industries are presented in table ;. While the overall size of the manutacturing sector did not change very much between 1979) and 1998 , and in fact it yielded employment to the service sector in the 1990/s, the characteristics of workers employed in manufacturing changed substantially, In $19^{-9}$, the average manufacturing worker had 8.2 years of education, and nearly halt of manufacturing workers had 6 years of education or less Those with 12 years of education or more amounted to only about a fifth of the total. By contrast, by 1998 , nearly half the manufacturing labor force had 12 years of education or more and only a fifth had 6 or fewer. Although the average education of workers in all industries increased between 1979) and 1998, the fastest increases took place in manufacturing and construction.

Within-industry shifts, however, were not the only factor contributing to increases in the demand for skilled labor. One interesting fact presented by table $;$ is that the average number of years of education for all Taiwanese workers increased by 2.9 years, which is greater than the increase for any single inclustry. This is possible because the employment share of more shill-intensive industries, particularly services, increased over time, absorbing many of the more celucated workers in the process. 
In summary, these changes suggest a large increase in the demand for skilled labor with two primary, driving causes: factor-specific technical change within the manufacturing sector and the expansion of the service sector.

\section{Returns to Education and Wage Inequality within Cohorts}

In order to measure differences in returns to education and wage inecutality across cohorts, data are used from the May supplements of Taiwan's monthly Labor Force Survey, which has been administered by Taiwan's DirectorateGeneral of Budgeting, Accounting, and Statistics every year since 1979. The survey is a household survey and asks detailed questions on wages earned, hours worked, and jobs held in addition to demographic informarion such as highest level of education attained and place of residence. The survey is limited to those age 15 and higher. Every year, the survey is given to approximately 19,000 households, which, at an average household size of slightly more than three members over 15 years of age, translates into approximately 60,000$)$ observed people each year, of whom about half participate in the labor force. In all, the data sets from 1979 to 1998 make up a substantial mergect data set, with $1,144,471$ individuals observed in total.

Throughout this analysis, four cohorts are examined in detail, consisting of Taiwanese born from 1929 to 1938,1939 to 1948, 1949 to 1958, and 1959 to 1968. Taiwanese from earlier or later cohorts generally did not spend enough of their working life between 1979 and 1998 to be useful as a basis for comparison. This section does not seek to provide a set of robust explanations for differences in returns to education and wage inequality across cohorts but merely to present a series of suggestive, stylized facts. The phrase "return to education" refers to a ratio of educated workers' wages to less educated workers" wages within cohorts. In most cases, the ratio is that of university graduates wages to lower secondary graduates' wages, though for robustness others are also examined.

There are two ways to compare differences in the recurn to education across cohorts without imposing parametric assumptions on earnings-- by holding time fixed or by holding age fixed. Figure 2 adopts the first method and shows the ratio of wages of men with a university degree or higher to those with a lower secondary qualification for each of the four cohorts over time.' It indicates that workers with a university education from older cohorts systematically received more of a return to their education than those from younger cohorts.

Too tiew women from the earliest two cohores attended university for a corresponding comparison to be sensible. For the later two cohorts, however, the results are gualitatively the same, thought women from those cohorts in general received higher returns to a university educition than men from the same cohort. 


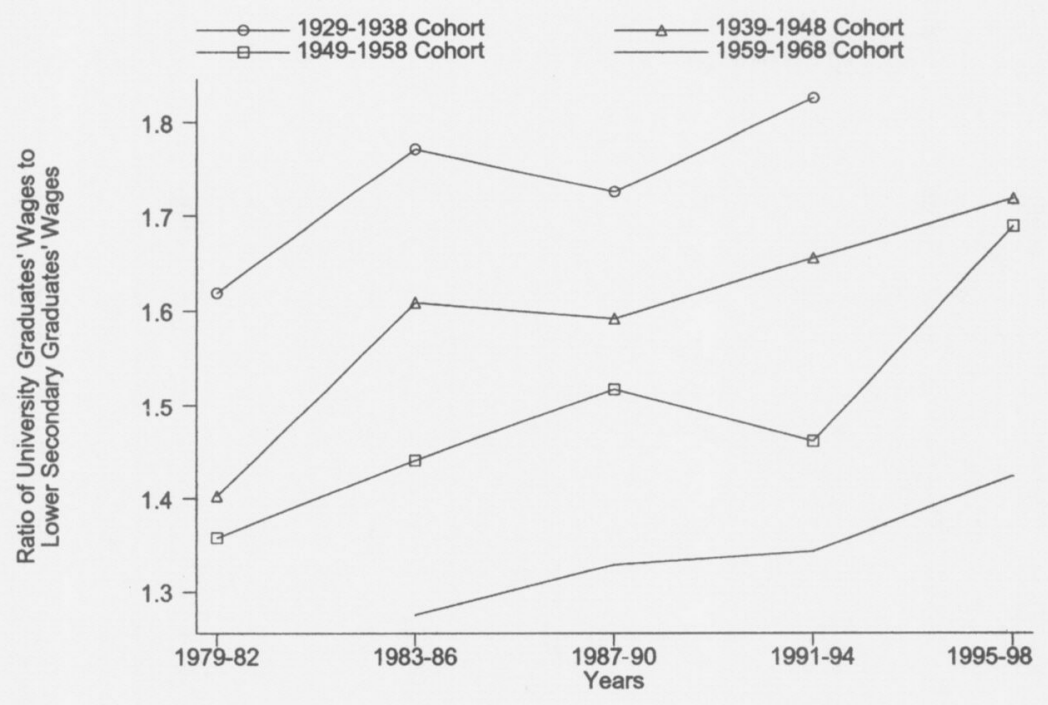

Figure 2. Relative return to education over time, by cohort (men)

There are two possible explanations for this phenomenon. The first is based (on the fiact that carlier cohorts are simply oleler; if the return to education increases with agre, it makes sense that older cohorts will have higher returns to education than younger cohorts. The second explanation is cohort specific, that there is something about older cohorts that makes an educated worker from such a cohort relatively more valuable. Providing that educated workers from older and younger cohorts are not perfect substirutes, whis might be the case if okter cohores are in general less educated, making educated workers from those cohores more scarce. Figure; sheds light on these possibilities, comparing the returns to education across cohorts when age is held fixed.

Figrure 3 indicates that, for all four cohorts, the relative return to a university qualification increases steply with age. Moreover, the age-relative earnings profile is remarkibly similar for all four cohorts; the variation in relative carnings is attributable more to variation in age than it is to differences in the cohorts themsetves. In fact, the hypothesis that the age-relative earnings protile is iclentical for all four cohorts cannot be rejected at the $1 \%$ level $(F=1.08 ; P=.0$ il). While a surprising finding for a country undergoing rapid technical and industrial change, it is consistent with the work of other rescarchers findings on the pattern of changes in Tawwan's wage structure (e.g., Gindling and Sun 2002). The most common explanation for the lack of change in the wase premium for education is the coincident large increase in the supply of educated gracluates, which mitigated the wage effects of Taiwan's ongroing industrial development. 


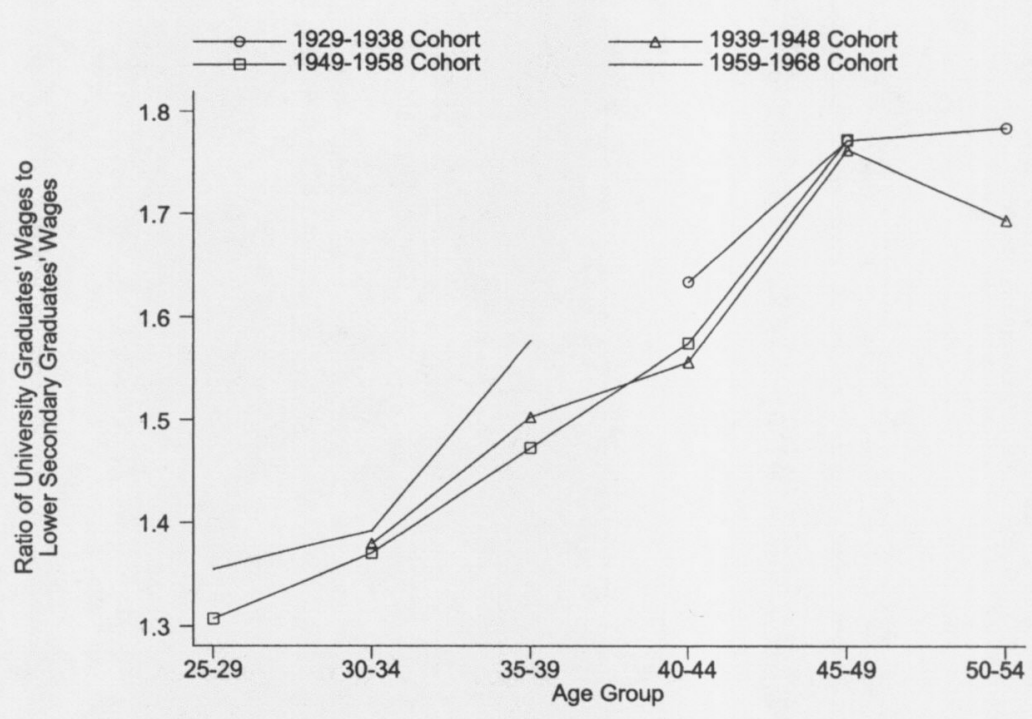

Figure 3. Relative return to education by cohort and age (men)

An alternate reading of figure 3 is that the relative return to a university qualification increases sharply with experience. It is worth pointing out that, within cohorts, common methods of imputing experience do not permit identifying an "experience effect" separately from an "age effect" in the preceding analysis. This is because, within cohorts, imputed experience is typically a linear combination of age and an education-specific constant (the age of leaving school). Therefore, controlling for age and education effectively controls for experience as well.

One of the puzzles presented by figure 3 is that it suggests that demandside factors had no influence on the wages paid to skilled labor in Taiwan, despite the significant changes in Taiwanese industry detailed earlier. A plausible explanation for this phenomenon is that there were demand-side effects on wages but that they were neutralized at the cohort level by large increases in the supply of skilled labor. One way to separate these ewo cffects is to examine the relative return to skill within industries. Since it is costly to switch industries, particularly after accumulating several years' experience, the supply of skill within cohort-industry groups tends to remain constant over time. However, switching firms within the same industry is a simpler matter, so wages should still be competitively determined within industries. Therefore, changes in the skill premium within cohort-industry groups reflect factorspecific technical change within that industry.

One obvious place to look for factor-specific technical change is the high technology manufacturing sector, which, following Kacz and Murphy (1992), 


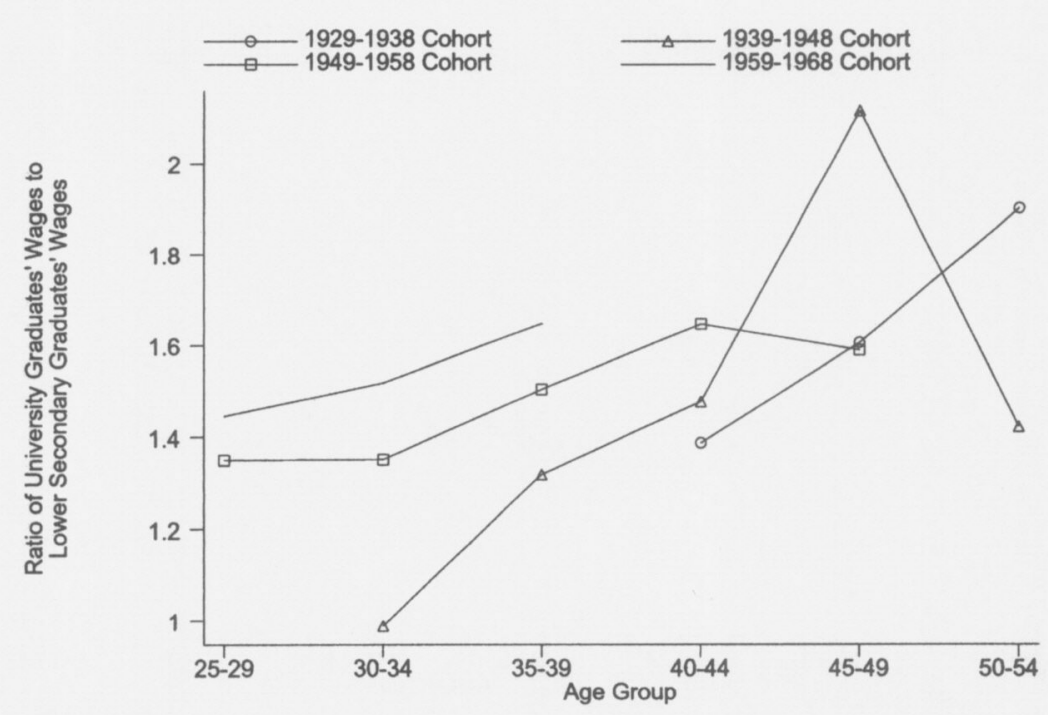

Figure 4. Relative return to education by cohort and age within high-technology manufacturing (men)

includes the chemicals, petroleum, plastics, and precision instruments industries. In 1989, these industries employed about 350,000 people, or about $13 \%$ of the total manufacturing labor forct. Figure it displays, for the four coloorts examined carlier, the relative return to a university education within this subset of manufacturing. For all cohorts, the age-relative carnings profile increases tairly steeply over time. Morcover, younger cohorts receive higher skill premiums than older ones, despite the fact that they are relatively more educated. 'This suggests that the demand for skilled labor has increased substantially over time in this sector.

Figure 5 examines low-technology industries that we know a priori not to have undergone rapid technical change. Again, using Katz and Murphy's (1992) definition, chese industries include apparel, textiles, and food. Amsden and chu (20)3) note that firms in these industries tended to focus more on diversifying their products offered rather than upgrading their manufacturing processes. These industries employed about $28 \%$ of the total manufacturing labor force in 1989. Here, the age-relative earnings profile is much flatter for each cohort, which suggests that factor-specific technical change proceeded much more slowly in these industries. In addition, younger cohorts received lower skill premiums than older ones, which is the reverse of the trend clepicted in figure 1 .

What this suggests is that, though increases in the supply of skilled labor tended to be cancelled out by increases in demand actoss industries, imbalances between these factors still drove wage structure changes within industries. 


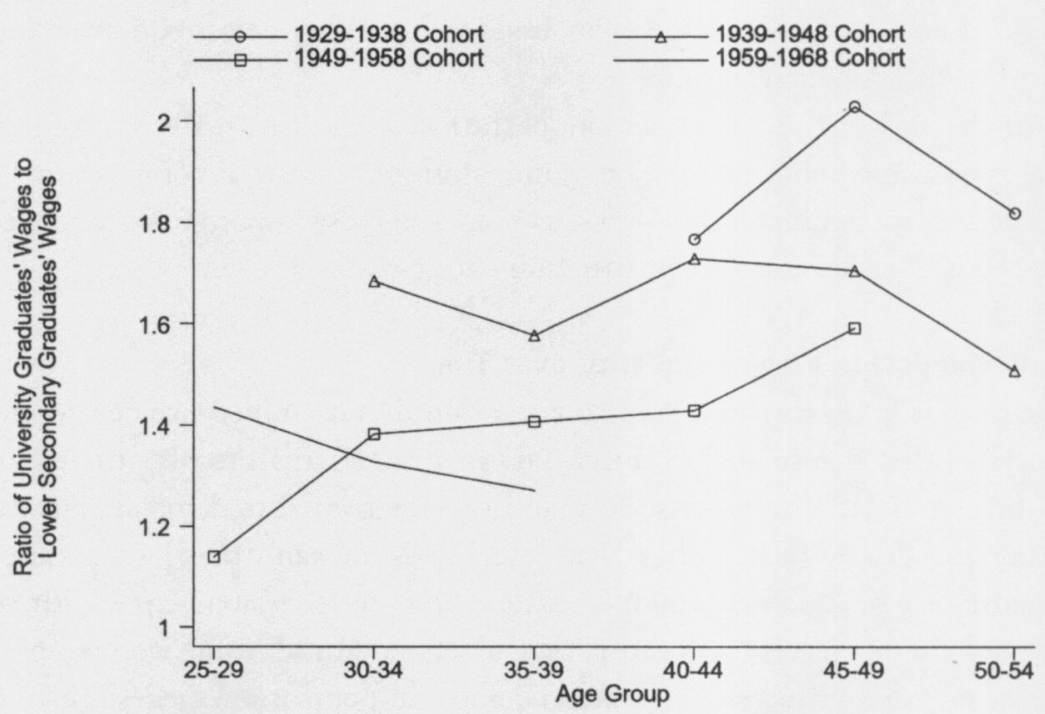

Figure 5. Relative return to education by cohort and age within low-technology manufacturing (men)

Within cohorts, returns to skill rise in industries where factor-specific technical change is more rapid and remain stagnant in others. Across cohorts, the dimension along which the supply of skill varies, returns to skill fall in more basic industries, though they rise in more advanced ones. Overall, these factors balance to produce the result in figure 3 .

When other levels of education are examined, the conclusions are qualitatively similar. Examining the wage ratio of upper secondary to lower secondary graduates, or that of secondary to primary graduates, differences between agre-relative earnings profiles across cohorts are of about the same order of magnitude as those shown in figure 3. The differences are, however, statistically significant, and to the extent they exist, younger cohorts tend to receive lesser returns to education than older ones. Examining these profiles within industries yields findings analogous to those shown in figures 4 and 5 .

In summary, these two sets of figures highlight two forces pushing inecuuality in Taiwan's wage structure in opposite directions. As shown by figures 2 and 3 , even though older cohorts receive greater returns to education than younger cohorts at any point in time, the age-relative earnings profiles faced by these cohorts have remained remarkably stable. However, since younger cohorts are more educated, wage inequality across cohorts declines as they enter the habor force.

By contrast, as figures 4 and 5 show, within-cohort age-relative earnings profiles have not remained stable within industries. As factor-specific technical change progresses in some, but not others, the relative earnings of more-and 
less-educated workers diverge. This leads to inequality across education levels within cohort-industry groups.

As the next section quantifies, out of the five factors this analysis considersthe other three being population aging, shifts in industrial composition, and the gender wage differential-these two are the most important in accounting for changes in 'Tawan's wage structure over time.

\section{Decomposing Wage Inequality over Time}

'The discussion in the preceding three sections has examined five development processes that may plausibly affect Taiwan's wage structure over time. Three of these are retated to labor supply, and two are related to demand. The most important supply-related shift that occurred is Taiwan's massive educarional expansion, which caused younger cohorts to enter the labor force with considerably higher levels of education than older ones. In addition, women entered the labor force in increasing numbers, and the population aged slightly. On the demand side, factor-specific technical change increased the demand for skilled labor within industries, especially high-level manufacturing. At the same time, the employment share of the service sector increased, which also tended to increase the demand for skilled labor.

The effects of these factors on the wage structure can be separated by decomposing the Theil index in the following way:

$$
\begin{aligned}
T= & \sum_{c=1}^{C} \frac{n_{c}}{n} \cdot \frac{\mu_{c}}{\mu} \ln \left(\frac{\mu_{c}}{\mu}\right)+\sum_{c=1}^{C} \sum_{s=1}^{S} \frac{n_{c s}}{n} \cdot \frac{\mu_{c s}}{\mu_{c}} \ln \left(\frac{\mu_{s c}}{\mu_{c}}\right) \\
& +\sum_{c=1}^{C} \sum_{s=1}^{S} \sum_{e=1}^{E} \frac{n_{c s e}}{n} \cdot \frac{\mu_{c s e}}{\mu_{c s}} \ln \left(\frac{\mu_{c s e}}{\mu_{c s}}\right)+\sum_{c=1}^{C} \sum_{s=1}^{S} \sum_{e=1}^{E} \sum_{g=1}^{G} \frac{n_{c s e g}}{n} \cdot \frac{\mu_{c s e g}}{\mu_{c s e}} \ln \left(\frac{\mu_{c s e g}}{\mu_{c s e}}\right) \\
& +\frac{1}{n} \sum_{c=1}^{C} \sum_{s=1}^{S} \sum_{e=1}^{E} \sum_{g=1}^{G} \sum_{i=1}^{n_{c s e g}} \frac{y_{c s e g i}}{\mu_{c s e g}} \ln \left(\frac{y_{c s e g i}}{\mu_{c s e g}}\right) .
\end{aligned}
$$

In this expression, $c$ indexes cohorts, $s$ indicates sectors or industries, $e$ represents education groups, and $g$ indexes genders. Further, $n, n_{c}, n_{c s}, n_{c s e}$, and $n_{c s e g}$ refer to the number of people in the population, the number of people in cohort $c$, the number of people in cohort $c$ within sector $s$, the number of people in cohort $c$ within sector $s$ of education level $e$, and the number of people in cohort $c$ within sector $s$ of education level $e$ and gender $g$, respectively. Similarly, $\mu, \mu_{c}, \mu_{c s}, \mu_{c s e}$, and $\mu_{c s e g}$ refer to the mean wage in the population and the corresponding conditional means. Note that consistent estimation of none of these parameters requires a correctly specified wage equation. Expression 
$y_{\text {csegi }}$ refers to the wage of individual $i$ belonging to that cohort-sector-educationgender group.

There are some general caveats to be made regarding the intcrpretation of results from this type of decomposition. First of all, (1) is not a structural model of wages. Since this is the case, the results do not have a causal interpretation. While they can show that the data are consistent with certain explanations of the path of inequality over time, conclusions about the most plausible direction of causality depend on prior knowledge of Tawwan's labor market. Second, each term is a function of a particular variable and all prior variables in the decomposition. For example, the second term measures between-sector wage inequality within cohorts. If cohorts were not included in the decomposition, this term would represent only between-sector wage inequality and have a very different interpretation. Because of this, adding more factors to the model could, in principle, change the results, and they must be interpreted very carefully with this in mind.

The first term in (1) quantifies wage inequality attributable to differences in wages between cohorts. As younger, more educated cohorts become more well represented in the labor force, inequality measured by this term should decline over time. This occurs because the effect of increasing the education of the youngest cohorts is to raise the average wages of a group wirh typically below-median earnings. That this will reduce the inequality index follows because the Theil index obeys the Dalton transfer principle.

The second term quantifies wage inequality attributable to differences in relative wages between industries within cohorts. This term captures the traditional Kuznets effect of the expansion of the industrial sector on inequality conly here the focus is on wage inequality, not income inequality as in Kuznets's original hypothesis). Industries are measured at the one-digit level. Although it may seem that industry has long overtaken agriculture in Taiwan, Ikemoto and Uehara $(2000)$ point out that the upward portion of the Kuznets curve can reappear as successively higher productivity industries enter the economy. Therefore, the expansion of the service sector and the replacement of lowertechnology industries by more advanced ones may cause inequality to increase.

The third term measures inequality due to differences in earnings across educational levels within cohort-sector groups. There are two factors that can cause earnings differentials within cohorts and industries to increase-factorspecific technical change, as described in the preceding section, and population aging as cohorts move up the age-relative earnings profile. It should be noted that, since both aging and factor-specific technical change result in increases in relative earnings over time, the effects of these processes cannot be separately identified. However, as population aging in Taiwan was not that intense (its 
TABLE 4

THEIL DECOMPOSITION OF WAGE INEQUALITY IN TAIWAN OVER TIME

\begin{tabular}{|c|c|c|c|}
\hline & Theil Index & Between Cohort & Between Sector \\
\hline \multirow[t]{2}{*}{1979} & .155 & .032 & .01 \\
\hline & $(.004)$ & $(.001)$ & $(.001)$ \\
\hline \multirow[t]{2}{*}{1984} & .143 & .02 & .019 \\
\hline & $(.002)$ & $(.001)$ & $(.001)$ \\
\hline \multirow[t]{2}{*}{1989} & .123 & .009 & .015 \\
\hline & $(.001)$ & $(.000)$ & (.001) \\
\hline \multirow[t]{2}{*}{1994} & .143 & .00 & .017 \\
\hline & $(.005)$ & $(.000)$ & (.001) \\
\hline \multirow[t]{3}{*}{1998} & .155 & .00 & .018 \\
\hline & $(.005)$ & $(.000)$ & $(.001)$ \\
\hline & Between Education & Between Gender & Within \\
\hline \multirow[t]{2}{*}{1979} & .029 & .014 & .06 \\
\hline & $(.002)$ & $(.001)$ & $(.003)$ \\
\hline \multirow[t]{2}{*}{1984} & .032 & .016 & .055 \\
\hline & $(.001)$ & $(.001)$ & $(.001)$ \\
\hline \multirow[t]{2}{*}{1989} & .030 & .017 & .051 \\
\hline & $(.001)$ & $(.000)$ & $(.001)$ \\
\hline \multirow[t]{2}{*}{1994} & .041 & .020 & .061 \\
\hline & $(.002)$ & $(.002)$ & $(.002)$ \\
\hline \multirow[t]{2}{*}{1998} & .052 & .016 & .066 \\
\hline & $(.002)$ & $(.001)$ & $(.002)$ \\
\hline
\end{tabular}

Note. Standard errors are in parentheses.

experience is similar oo that in the United States berween 1980 and the early $190($ ) and it was spread out over an interval nearly twice as long), it is reasonable to surmise that factor-specific technical change makes up most of the effect identified by this term.

Finally, the fourth term captures wage inequality due to differences in relative wages of men and women within cohort-sector-education cells. Since women entered the labor force at all educational levels, but the gender wage differential did not move in the same direction for all of these, the direction of change of this eerm is unclear. However, most women entering the labor force until 1902 were relatively unskilled, and the gender wage differential worsened for less-skilled women over time (in the early 19sos, the skilled women were, for the most part, already in the labor force l Zveglich et al. 1997 7). Therefore, the influx of these women, since their watges declined even as their numbers increased, should cause inequality to increase.

Table if presents the resules of this decomposition over time for workers in Tawan born between 1939) and 1968." The between cohore, berween sector, between education, between gender, and within columns refer to the first,

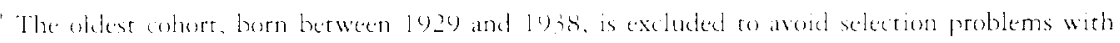

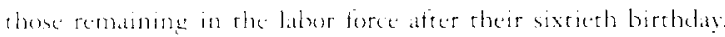


TABLE 5

PERCENT CONTRIBUTION OF BETWEEN-COHORT, BETWEEN-SECTOR, BETWEEN-EDUCATION, BETWEEN-GENDER, AND WITHIN CHANGES TO OVERALL CHANGES IN WAGE INEQUALITY

\begin{tabular}{lccc}
\hline & Theil Index & Between Cohort & Between Sector \\
\hline 1979-89: & & & \\
Absolute Change & -.032 & -.023 & -.002 \\
Percent Change & 100.0 & 71.5 & 6.0 \\
1989-98: & .032 & -.007 & .003 \\
Absolute Change & 100.0 & -21.8 & 9.6 \\
Percent Change & Between Education & Between Gender & Within \\
\cline { 2 - 4 } & & & \\
ny79-89: & -001 & .003 & -.012 \\
Absolute Change & -3.8 & -10.9 & 37.2 \\
Percent Change & .022 & -.001 & .015 \\
1989-98: & 68.1 & -4.2 & 48.2 \\
Absolute Change & & & \\
Percent Change & &
\end{tabular}

second, third, fourth, and fifth terms in (1). Overall, as measured by the Theil index, wage inequality decreased between 1979 and 1989 and then increased thereafter, until by 1998 it was at nearly exactly the same level it was in 1979 . Underlying this $U$-shaped trend, however, are two important factors. The between sector and between gender columns, representing the effects of changes in industrial composition and the feminization of the labor force, turn out not to be that significant. However, the educational expansion contributed substantially to the decline in wage inequality in the 1980 s, and factor-specific technical change accounts for a large portion of the increase in the 199()s.

To clarify this point, table 5 shows the percentage contribution of each of these components to the 1979-89 decrease and the 1989-98 increase in wage inequality. It can be seen that the contribution of between-cohort shifts to the decline in inequality in the $1980 \mathrm{~s}$ is considerable, exceeding $70 \%$; the contributions of other factors are relatively minor. As for the increase in inecuality in the $1990 \mathrm{~s}$, between-education shifts are the most important factor, accounting for nearly $70 \%$ of the total change. This suggests that Taiwan's educational expansion was the most important factor compressing wages in the 1980 and that factor-specific technical change was the most important factor dispersing wages in the 1990s. However, for reasons to be outlined below, these measures may understate the effects of changes in industrial composition.

Even after examining all of these factors, the within component still accounts for a fair amount of the total trend in wage inequality in the 1980s and 1990s. Therefore, it is useful to think carefully about what the within component constitutes. By the nature of the Theil decomposition, the magnitude of the 
within component depends on the fineness of the groups used to meatsure the between components. It will, mechanically, shrink if more variables are added to the decomposition or existing variables are broken up into finer categories. In this way, it is analogous to the sum of squared residuals in an ordinary least syuares regression.

()ne limitation of the data is that, since Tawan's industrial classification system has undergence a number of changes between 19) and 1998, the inclustry codes across years are comparable only at the single-digit level. Expansion of skill-intensive categories within these categories will go unmeasured by the Theil decomposition. Moreover, it is fairly likely that at least some displacement of this type occurred. One example is the expansion of the cellular phone industry in the 1990 s, which tended to displace the manufacture of notebook computers (Amsden and Chu 2003). If these products were in different single-digit industries, the between-sector measure would capture the effects of this expansion on the wage structure. But since both of them fall within the same single-digit industry, within inequality is the result. Therefore, part of the change due to the within component maly reflect finer changes in industrial composition, especially in later years.

\section{Conclusion}

One of the difficulties in explaining changes in wage inequality, especially in more recently developing countries, has been the existence of many potential reasons for these changes. While these factors tended to be successive in the experience of the Enited States and Western Europe, they were more simultancous in countries that started to industrialize afeer World War II. As a resule, the literature has been divided as to whether the experience of earlier developing countries is still relevant, and if so, how. For example, Fields (1980) observes that the postwar educational expansion in a number of countries was not followed by reductions in wage incepuality. At the sime cime, expected increases in wage inecuality have not always eccurred either; studying Taiwan, Gindling and Sun $(2002)$ find virtually no evidence for demand-driven changes in the wage structure, despite a manifest sea change in the character of local industrics.

One clear possibility is that these processes have tended to neutralize each other, chereby making the effect of any one difficult to discern in isolation. The secmingly unchanging relationship between age and returns to education across cohorts in figure 3 is consistent with and underscores (iindling and Sun's $(2002)$ findings. But alchough one interpretarion of figure 3 is that neither the supply of nor the demand for skilled labor in Taiwan changed appreciably over time, a more likely interpretation is that they moved in lock 
step with one another, at least at the cohort level. Due to this stability, the higher educational attainment of younger cohorts increases their carnings relative to older ones and causes berween-cohort inequalicy to decline over time.

When relative returns to education within cohorts are examined at the industry level, however, mismatches start to occur. Within cohort-industry groups, these returns rise quickly in industries undergoing rapid technical change and remain stagnant in others. If, as seems probable, these increases are the result of factor-specific technical change, the implicarion is that factorspecific technical change increases between-education inequality within cohortindustry groups. Similarly, the expansion of high-wage industries can be expected to increase between-industry inequality within cohorts, and the feminization of the labor force may affect between-gender wage differences within cohort-industry education groups.

Since these development processes intuitively correspond with nested measures of between-group inequality, a multiple-stage Theil decomposition is a sensible way to measure the relative contribution of each. It should be stressed that, although the Theil decomposition is useful in examining whether the data are consistent with one hypothesis or another, the results cannot establish causality in and of themselves. Moreover, results for a particular factor must be interpreted very carefully in light of the fact that they are dependent on, and can change with, the other factors included in the decomposition. The results are consistent with the assertion that, while Taiwan's educational expansion was an important factor reducing wage inequalicy in the 1980 ), factorspecific technical change accounted for a significant portion of the increase in the 1990s. The other factors were less important, though, since industries could only be measured at the one-digit level, the importance of the expansion of high-wage industries may be understated.

Taiwan's experience suggests that the relationships between wage inequality and development processes established before World War II are still relevant to developing countries today. But since supply-and demand-related factors tend to cancel one another out, their relative importance is difficult to determine, at least where prices are concerned. The multiple-stage Theil decomposition avoids this problem by implicitly holding supply fixed within cohortindustry groups, which allows these effects to be separated. Therefore, future researchers may find it useful in identifying the effects of these processes on a country's wage structure.

\section{References}

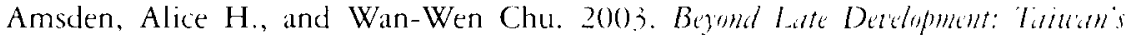
Upgrading Policies. Cambridge, MA: MIT Press. 
Clark, Diana E, and Chang-Tai Hsieh. 2(0)0. "Schooling and Labor Market Impact of the 1968 Nine-Year Felucation Program in Taiwan." Linpublished manuscript, Department of Economics, University of California, Berkeley.

Deaton. Angus, and Christina Paxson. 1994. "Intertemporal Choice and Inecuality."

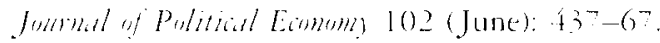

Fields, Carty S. 1998. "Education and Income Distribution in Developing Countries:

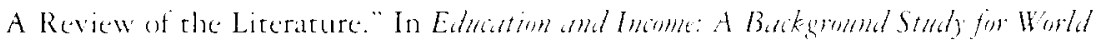
Dotupment Repent. 19S\%, ed. Timothy King. Washington, DC: World Bank.

Fields, Gary s.. and Jennifer C. O'Hara Mitchell. 1999. "Changing Income Inequality

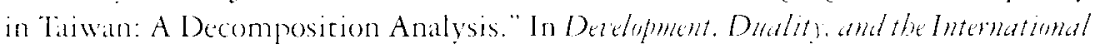
Eommmir Regime, de. Gary R. Saxonhouse and T. N. Srinivasan. Ann Arbor: Lniversity of Michigan Press.

Gereffi, Gary, and Mei-Lin Pan. 199.t. "The Globalization of Taiwan's Garment

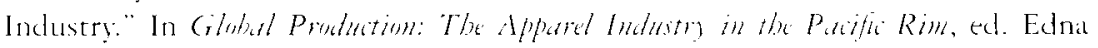
Bonacich, Lucie Cheng, Norma Chinchilla, Nora Hamilton, and Paul Ong. Philadelphia: Temple University Press.

Gindling, 1: 11., Marsha Goldtarb, and Chun-Chig Chang. 1995. "Changing Returns ro Education in Taiwan, 1978-9)." World Deqelepment 23 (February): 3.3-56.

Gindling. T. H., and Way Sun. 2002. "Higher Education Planning and the Wages

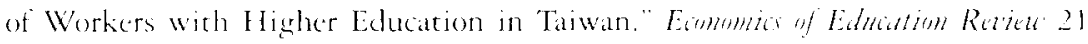
(Aprill: $153-69$.

Gold. Thomas B. 1986, State and Sicien in the Tainan Wiwh. New York: M. E. Sharpe.

Goldin, Clatudia, and Lawrence F. Katte 1999). "The Returns to Skill in the United States acrosis the Twentieth Century." Working Paper no. 7126, National Bureau of Economic Rescarch. Cambridge. MA.

Hermalin, Albere I., Patul K. C. Liu, and Deborah Freedman. 1 y9f. "The Social and Economic Transformation of Taiwan." In Swial Chomge and the Family in Tailuan, ed. Arland Thornton and Hui-Sheng Lin. Chicago: University of Chicago Press.

Ikicmoro, Yukio, and Mine Lehara. 2000. "Income Ineculality and Kuznets' I Iypothesis in Thailand." Avan Eommong Joumal $1+$ (Decomber): $121-13$.

Jiang, Fengr-Fuh. 1992. "The Role of Educational Expansion in Taiwan's Economic Development." Inderty of Five Chin 77 (April): 37-68

Juhn, Chimbui, and Dat Il Kim. 1999. "The Effects of Risingr Female Labor Supply on Male Wages." Jommal of Labur Eomemica 17 (January): 23-48.

Katz, Lawrence F., and Kevin M. Murphy, 1992. "Changes in Relative Wages, 196.3-198-: Supply and Demand Factors." Quaterly foumal of Eommonio 107 (February): $35-78$.

Kuznets, Simon. 1955. "Economic Growth and Income Inequality." Americun Eomomiti Retiun 45 (March): $1-28$.

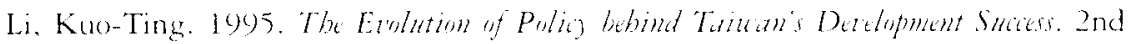
ed. Singilpore: World Scientific.

Ohtake, Fumio, and Makoto Saito. 1998. "Population Agring and Consumption Inecululity in Japan." Reriew of Intame and Wealth it (September): 361-81.

Saxenian. AnnaLee, and Jinn-Yuh Hsu, 2001. "The Silicon Valley-Hsinchu Con- 
nection: Technical Communities and Industrial Upgrading." Industrial and Corporate Change 10 (August): 893-920.

Schive, Chi, and Jenn-Hwa Tu. 1991. "Foreign Firms and Structural Change in Taiwan." In Direct Foreign Investment in Asia's Developing Economies and Strutural Change in the Asia-Pacific Region, ed. Eric D. Ramstetter. Boulder, CO: Westview. Schultz, T. Paul. 1999. "Income Inequality in Taiwan, 1976-95: Changing Family Composition, Aging, and Female Labor-Force Participation." In The Political Economy of Taiuan's Development into the Tuenty-First Century, ed. Gustav Ranis, ShengCheng $\mathrm{Hu}$, and Yun-Peng Chu. Cheltenham, U.K.: Edward Elgar.

Tsurumi, E. Patricia. 1977. Japanese Colonial Education in Taiu'an. 1895-1945. Cambridge, MA: Harvard University Press.

van Hoesel, Roger. 1999. New'Multinational Enterprises from Korea and Taiuan: Beyond Export-Led Growth. New York: Rourledge.

Wade, Robert. 1990. Governing the Market: Economic Theory and the Role of Government in East Asian Industrialization. Princeton, NJ: Princeton University Press.

Zimmer, Zachary, Xian Liu, Albert Hermalin, and Yi-Li Chuang. 1998. "Educational Atrainment and Transitions in Functional Status among Older Taiwanese." Demography 35 (August): 361-75.

Zveglich, Jr., Joseph E., Yana van der Meulen Rodgers, and William M. Rodgers. 1997. "The Persistence of Gender Earnings Inequality in Taiwan, 1978-1992." Industrial and Labor Relations Revieu 50 (July): 594-609. 